\title{
CYBERMEDIA ECONOMICS: REVENUE MODEL AND SOURCES OF FINANCING
}

\author{
María-Nereida Cea-Esteruelas
}

Nota: Este artículo puede leerse traducido al español en:

http://www.elprofesionaldelainformacion.com/contenidos/2013/julio/12_esp.pdf

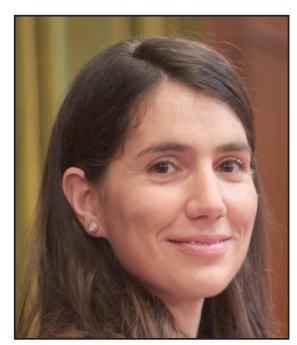

María-Nereida Cea-Esteruelas has a PhD in Information Science from the University of Navarra and master's degrees in Digital Journalism (University of the Basque Country) and Interactive Advertising (Complutense University of Madrid). She is a member of the Labcom research group (University of Málaga) and has worked as a journalist in La verdad (Grupo Vocento), La economía (Grupo Intereconomía) and El mundo (Unidad Editorial). In the area of political and institutional communication, she was responsible for communication at the Chamber of Commerce of Murcia and an advisor at the Ministry of the Presidency of the Autonomous Community of the Region of Murcia. Currently, she teaches in the Granada School of Communication (ESCO) and contributes to the economic magazine Cinco días.

http://orcid.org/0000-0002-7733-9366

Granada School of Communication (ESCO) San Antón, 73. 18005 Granada, Spain nereidacea@gmail.com

\section{Abstract}

The paper proposes an approach to the study of the economics of cybermedia, with the aim of describing the structure and economic logic of communications and cultural industries on the Internet. Given the breadth of the subject, the article analyzes the economics of cybermedia by studying the competitive model of the industry, describing the main actors involved in this market and analysing the business and financing model of cybermedia, with a focus on revenue structure.

\section{Keywords}

Internet, Cybermedia, Online media, Communications sector, Information economics, Competitivity, Business models.

\section{Título: Economía de los cibermedios: modelo de ingresos y fuentes de financiación}

\section{Resumen}

Se propone una aproximación al estudio de la economía de los cibermedios, con el objetivo de describir la estructura y lógica económica de las industrias comunicativas y culturales en internet. Dada la amplitud del tema, se parte del estudio del modelo competitivo de la industria, la descripción de los principales agentes que participan en este mercado y el análisis del modelo de negocio (y por lo tanto de financiación) de los cibermedios, centrando esta cuestión en su estructura de ingresos.

\section{Palabras clave}

Internet, Cibermedios, Medios online, Sector de la comunicación, Economía de la información, Competitividad, Modelo de negocio.

Cea-Esteruelas, María-Nereida (2013). "Cybermedia economics: revenue model and sources of financing". El profesional de la información, julio-agosto, v. 22, n. 4, pp. 353-361.

http://dx.doi.org/10.3145/epi.2013.jul.12

\section{Introduction: methodology and objectives}

This article serves a dual purpose: first, to propose a theoretical framework for the study of the economic logic of cybermedia (or online media), and second, to address the main features of the business model of communications companies. The first part takes a conceptual perspective, which is complemented by an observational approach to the business model analysis.
The economic logic of online media is addressed in four sections: consideration of the economic value of information; information on the Internet as an economic good, but with certain specificities; conceptual delineation of the study area within the media economy; and the economic structure of the online media. This section is based on the business model concept defined by Timmers (1998) and includes a description of the characteristics of online media as 
a product, the competitive environment and the financing sources. Since the characteristics of the online media have already been widely discussed in other studies (Cebrián, 2009; Salaverría, 2005; Díaz-Noci, 2008; Guallar; Rovira; Ruiz, 2010), this article focuses on the competitive environment and sources of financing. We analyse the competition faced by the new model of online content distribution, and the emergence of new companies in the sector that aggregate content generated by third parties and derive revenue. We also discuss the revenue-generating potential of transmedia distribution. Finally, with regard to the study of the sources of financing, we propose a joint description of the business structure and a detailed analysis of the two main sources: advertising and paid content.

\section{From the economic value of the information to media economics}

For the study of information, regardless of the medium through which it is distributed, it has economic properties because in the market it has a value; it has innate status as an economic good (Millán, 1993, p. 9). Referring to the nature of information as a commodity with an exchange value, Jones (2005, p. 27) said: "Despite ideological differences, nowadays nobody doubts that communicative and cultural products, in addition to social influence, are goods that reach a certain price in the market and have an exchange value. Therefore, the fact that communications and culture are directly or indirectly held by specific companies means that, throughout the process by which a work is created and finally reaches its destination (ie, in production and distribution phases), the first step converts it into a commodity."

\section{Information is an economic good because} it has a value in the market

While information is a product with a conferred economic character, its nature is not only economic, and is characterized by the specificity of having a dual purpose (TallónGarcía, 1992; Albarran, 1996; Nieto; Iglesias, 2000; Taúler; Población, 2000). That innate condition of information as an economic good subject to certain specificities remains unchanged on the Internet.

If we go a step further, we see how economic activities emerge around information -that is, information activitiesthat organize its production, distribution and consumption according to industrial and commercial standards. The set of activities carried out by media companies converts them into economic institutions (Albarran, 1996, p. 3).

These economic institutions are the communications media or companies that, as a group, shape a specific industry (Albarran; Chan-Olmsted, 1998, p. 3). Information goods are produced and distributed by media or communications companies. Its supply and demand create the information market or industry. More precisely, as stated by Albarran and Chan-Olmsted (1998, p. 6), "the market consists of buyers and sellers (...) although traditionally, the study of the media economy focus on the supply side, ie, in communications companies."

\section{Cybermedia economics}

In the study of information and the new media on the Internet -whether analysed as a cultural industry (Bustamante, 1998; Miguel-de-Bustos, 2000; Bustamante, 2002) or by other, more Anglo-Saxon, microeconomic approaches such as information enterprise or, more recently, the media economy- a complementary and interdisciplinary approach is of great interest. This approach allows the integration of the specificities of communications and cultural industries with an economic analysis of the digital market. Thus, the study of communications markets would be enriched with specific contributions from other disciplines that share the study of information, such as the information economy (Shapiro, Varian, 2000), and from microeconomics branches, such as the new economy (Tapscott, 1997) or the attention economy (Goldhaber, 1997).

While the information economy would focus on information as a global production system subject to certain economic laws and the logic of business interests, the economics of communications and culture would study the production forms, the characteristics of the cultural goods and the capital appreciation in each branch. For the present article, media economics is the study of how industries use scarce resources to produce content that is distributed to consumers to satisfy their desires and needs. In this sense, media economics helps to understand the economic relations between producers, audience, advertisers and society (Albarran, 1996, p. 5).

From that same microeconomic perspective, Picard (1989), Doyle (2003), Owers, Carveth and Alexander (2004) and Albarran (2010) defined media economics as the study of trade and financial activities of the companies that produce and sell media.

So far, studies of the media economy have analysed different communications markets and, using empirical microeconomic analysis generally based on case studies, established a theoretical framework that defines the main industries. Albarran defines three major sectors in his book, Media economics (1996):
- print edition of newspapers, magazines and books;
- radio and television (including cable and satellite);
- film and music industry.

In subsequent publications related to media economics, the new media (online media) would be added to these sectors. Brody (2000, pp. 248-267) is one of the first authors to propose their study as an industry differentiated from traditional media. The distinctive outline of this new industry varies in subsequent studies, but initially, in addition to cybermedia, it included access and content providers.

The study of online media as a communications industry separate from the rest does not invalidate other approaches, also from the media economy, to analyzing market information on the Internet as an extension of traditional media and therefore evaluating their impact on the business model of the press, radio or television. From that perspective, Doyle published Understanding media economics (2002), a book describing the new media economy based on its impact on the traditional media business model. 
Other authors follow the same context of comparative study of media to address specific issues such as competitiveness on and offline (Chyi; Sylvie, 1998), differentiation strategies (Carveth, 2004, pp. 214-247), the effect of Internet in the decline of traditional media difusion (Fetscherin; Knolmayer, 2004) and its impact on profitability (Chyi; Sylvie, 2010).

Since the publication of these contributions to the literature, cybermedia (digital media, new media, online media) have been studied as a communications sector differentiated from traditional media. Indeed, given the need to study the impact of the Internet on existing industries, we understand thatthere is a new information market, whose features set it apart from both the print and the audiovisual markets (Cea-Esteruelas, 2009, pp. 938-950; 2010, pp. 31-43). As stated by Herrero (2002, p. 189) "the type of product or service is what allows the classification of a company or industry." Applying the model for the study of other media to the Internet, we analyze the market structure, the features that define its operation and companies of the sector (Albarran, 2005, p. 117).

Along with traditional media companies, there are emerging Internet exclusive companies (native or pure players) and various types of conten and information generators

\section{Business model of cybermedia}

The concept of a business model has been extensively studied in other disciplines (Rayport; Sviokla, 1995; Timmers, 1998; Amitt; Zott, 2001, Casero-Ripollés, 2010; Magreta, 2002; Shafer; Smith; Linder, 2005; Ricart, 2009). Since delving into this concept exceeds our task, we apply the definition provided by Timmers (1998), who considers that the business model has three parts:

-product features;

-description of the actors involved in the business; -sources of financing.

Following this definition, and ignoring the description of product features widely covered by other authors, we will describe the economic logic of the cybermedia business model, following three directions: 1) analysis of the competitive environment and the main actors involved in the sector, 2) general overview of the revenue model, and 3) main sources of financing.

It should be noted that some authors propose business model definitions that also include issues such as organizational goals, strategy or the value chain. However, as noted by Ricart (2009, p. 14), the business model is primarily concerned with "how businesses generate income on the Internet."

\subsection{Competitive environment}

The competitive environment of cybermedia is the digital marketplace, or marketspace, a term coined by Rayport and Sviokla (1995). Among the features of the digital envi-

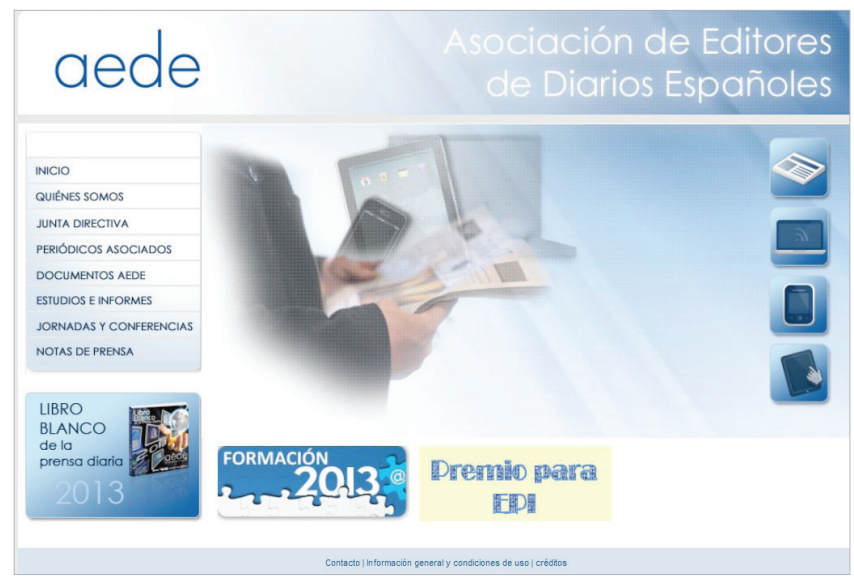

http://www.aede.es

ronment that affect the cybermedia business model, they highlight the low entry barriers to new exclusively internet companies (pure players). These new agents compete with traditional media for internet advertising revenues, an income stream that is increasing as audiences migrate to digital environments (Casero-Ripollés, 2010, p. 597, Rojo-Villada, 2008, p. 118) .

In this competitive environment, new opportunities are created while challenges arise for the transposition of traditional business models to the Web. This is the case of the intellectual property conflict that the Association of Spanish Newspaper Publishers (Asociación de Editores de Diarios Españoles, $A E D E$ ) holds with Google and other aggregators and search engines (Yahoo, Bing, etc.). The commercial use of news fragments called snippets (headline and 3 first lines) causes an economic harm to publishers, so they urged the authorities to establish the so-called "Google tax"1 to recoup losses from aggregators. However, in a free market competition, the difficulty of monetizing editorial content reflects not only the competition from Google and other aggregators, but also a distribution model that modifies the value chain.

In the online distribution, content is freed from the continent (the format), fragmented and distributed through social networks. With RSS (really simple syndication) and other systems, any user can create an individualized news service, selecting custom content from various sources. As noted by Bolin (2007, p. 246), in the era of technological convergence, content becomes more fluid and therefore more difficult to control and capitalize.

In fact, the same basic problem posed by editors regarding news aggregators can be extended to music aggregators like Ivoox, or audiovisual ones like YouTube. Using RSS and following the same Google News model, countless content aggregation services are emerging, some focused on social content (eg Reddit), social network and design (Flipboard), and the mobile environment (Feedly) and some whose core content comes from the media: Zite, developed by $C N N$, has among its partners publishing groups like The daily beast, FOX sports, HLN TV, The Huffington post, Motley fool, The next web and VentureBeat.

These content aggregators have been able to create a product financed by advertising and by subscriptions, while tra- 
ditional content providers find it difficult to monetize the same content in their platforms.

Another characteristic of the competitive environment that determines the cybermedia business model is the transmedia distribution of digital content, which is favoured by the low distribution costs and the proliferation of digital media platforms and channels, including mobile ones. Transmedia distribution is related to multi-platform distribution (crossmedia). As defined by Scolari (2013), referring to the transmedia concept, it is "a very specific type of cultural production or speech where a) the story expands through various media and platforms, and b) users participate in this expansion".

Transmedia products provide undeniable aesthetic and artistic resources, and financial incentives exist in the digital economy for their production (Bolin, 2007, p. 246) because they create unprecedented opportunities for the exploitation of the product value in the universe of multimedia content (Champion; Doyle; Schlesinger, 2013, pp. 2-3). Transmedia products require innovative ways to tailor content to different platforms / distribution screens (PC, tablet and smartphone). This adaptation ranges from the technological peculiarities of format or behavioural use model of each platform to the content marketing model.

On the Internet, traditional media companies compete with a host of new agents that also function as advertising plattforms

\subsection{Revenue model}

Before analysing in detail the two main sources of financing -advertising and payment for content- we should review the various studies that will allow us to describe the economic structure of cybermedia.

The economic analysis of any communications sector is a truly complex task due to the lack of transparency. This is accentuated in the case of companies or business areas within the communications group that have internet and new media activities. There are two reasons for this difficulty: the transversality of its activity and, consequently, of their income, and the tendency to fragment many of their expenses. The accounting information of these companies is public, according to the terms established in the Ley general presupuestaria (General appropriations act); however, generally they either do not provide details or do not reflect the true picture, introducing a high degree of opacity within the group accounts.

This explains the lack of professional or sectoral studies that provide information on the business structure and the percentage of revenue contributed to the cybermedia by each source. In this regard, we note a seminal report conducted by the European Association of Online Publishers (2004) that managed to collect economic data on the major European media companies and the financing structure of their respective internet areas.
We would highlight the work by Wirtz (2011, p. 75), which provides data on the revenue structure of the Internet area of communications groups and comparatively with respect to other sectors (newspapers, television, radio, etc.). Some microeconomic studies have been published that use case studies to analyze Internet media within large media groups like Prisa (Cea-Esteruelas, 2009), Mediaset (Colapinto, 2010) or the Portuguese Media Capital Group (Faustino, 2007 ).

As stated in these studies -and as happens in other media companies-, practically all cybermedia revenues come from two sources:

- Advertisers, who generate revenue through advertising;

- Users, who generate revenue through direct payment, also known as paid content.

The description of a business model often lists other sources of financing such as micropayments, subscriptions, classified ads, mobile apps revenue, content syndication, advertising, other advertising revenue (affiliation networks ${ }^{2}$, Google, etc.). The completeness of some lists of revenue models, and the rapid innovations they are experiencing (falling into disuse or adopting many variants), suggests the need to elaborate a sound classification unshakable by these rapid changes.

Whereas the aforementioned revenue sources correspond with any of the two generic types, advertising and payment for content, advertising revenue would also include graphic advertising, text advertising, classifieds, search engines, affiliation networks, etc. Moreover, within payment for content, in addition to the subscription we would include the different types of micropayment, syndication and aggregation, content block sales and donations made by the users to support the content.

Depending on the economic weight adopted by each financing source (advertising and content payment), a mixed financing structure can be defined in which the percentage of each one varies. Thus, the greater or lesser importance acquired by paid content, compared to the proportion of free content, allows differentiation between business models. As noted by Casero-Ripollés (2010, p. 598), within the payment-free dichotomy we can establish the following types: free (advertiser-supported), total payment (pay-wall) ${ }^{3}$, metered model, freemium and donations.

In conclusion, a mixed model adapts a financing structure ranging from free to fee-for-content based on content type. As Diezhandino (2012) noted, "the future of journalism will necessarily go through a mixed model that mixes information payment and advertising funding." Indeed, on the Internet, as in other media such as television, it is not so much the medium that defines the revenue model, but the type of product -in this case, information-.

\subsection{Sources of funding}

According to the report of the European Association of Online Publishers on the economic structure of cybermedia, advertising revenues have been the main source of financing, providing $89 \%$ of total revenues (Oelbermann et al., 2004, p. 14 ). The second source is payment for content, primarily 
through the sale of news, which accounts for $11 \%$ of total revenue.

More recent studies show that the structure of financing in cybermedia has not changed substantially. After evaluating the information provided by 13 communications companies representing 330 newspapers in the United States, and interviews with its executives, a study led by Rosenstiel for the Pew Research Center Project for Excellence in Journalism (2011) concluded that graphical and classified advertising ${ }^{4}$ was the main source of revenue, contributing $76 \%$ of total turnover in this sector in 2011. Meanwhile, mobile advertising accounted for $1 \%$, although all managers believed that it would experience growth over the coming years. Also, the so-called daily deals, equivalent to coupon sales commissions (Groupon type), accounted for $5 \%$ of revenues. Payment for content, although considered a basic financing source for the sector, showed no signs of growth and provided the remaining income (around 10\%).

\section{The information, which once used to be scarce and therefore valuable, now is so ubiquitous that it becomes almost de- void of value}

Other academic studies similarly described the revenue structure of the cybermedia sector. After analyzing this sector in the United States, Wirtz (2011, p. 75) concludes that advertising generates $82 \%$ of cybermedia revenue, compared to $18 \%$ from other miscellaneous income, most coming from the sale of content. If Internet and other media are compared, it appears that only television and radio receive more advertising funding $(92 \%$ and $87 \%$ of all advertising revenue, respectively). In third place is the Internet (82\%), with a greater contribution of advertising revenue in its income statement than is reported by press and magazines (75\%).

\subsection{Paid content and other funding sources}

With the experience gained after several attempts to establish payment for content, since 2011 the mainstream media try to boost Internet subscriptions by reinforcing premium content. Thus, they are seeking a mixed model that provides equity between free and payment services. In Spain, the

\begin{tabular}{|l|c|c|}
\hline \multicolumn{1}{|c|}{ Media } & $\begin{array}{c}\text { Advertising } \\
\text { revenue } \%\end{array}$ & $\begin{array}{c}\text { Sales revenue } \\
\%\end{array}$ \\
\hline Newspapers and magazines & 75 & 25 \\
\hline Books & - & 100 \\
\hline Cinema & - & 100 \\
\hline Television & 92 & 8 \\
\hline Radio & 87 & 13 \\
\hline Music & - & 100 \\
\hline Videogames & - & 100 \\
\hline Internet & 82 & 18 \\
\hline
\end{tabular}

Table 1. Revenue structure by type of medium (Wirtz, 2011, p. 75) major media companies such as Unedisa, Prisa and Vocento, opt for multiplatform distribution as an incentive to increase the paid content. Payment platforms like Orbyt (from Unedisa) and Kioskoymás (developed jointly by Prisa and Vocento, and involving RBA, Axel Springer, Zeta and Godó groups) offer valuable content beyond the mere redistribution of their newspapers in html or pdf format. For this reason, they have created closed platforms for subscribers that are differentiated from their web editions. The differential value of Kioskoymás and Orbyt is an offering that includes dozens of publications (newsstand) and the experience of belonging to an exclusive "readers club" with benefits and promotions such as discount coupons, VIP tickets to certain shows and exhibitions, etc.

Content payment combined with advertising, following the freemium model (a combination of free content and premium payment) is undergoing major development in the digital leisure industry, especially in the field of entertainment and music. The success of subscription streaming for the music market (like Spotify, VEVO or Deezer) and video on demand (Netflix, Hulu and soon YouTube) suggests an evolution towards the subscription in the paid content model compared to micropayment that, so far, has been successfully operated by the music industry, if one looks at iTunes.

The boom of sites like Netflix -audiovisual content social aggregator-, to become the leading pay TV with 30 million subscribers, reveals how new agents (pure players) have created new products following the model of aggregating content from other sources and suppliers, competing fiercely with traditional broadcasters and implementing marketing formulas able to monetize content in the digital environment.

Along with advertising and payment for online content, there are other ways to fund journalistic projects, via sponsorship and donations from users. Among the references of the so-called crowdfunding journalism are digital newspapers as Diagonal, Información sensible and MasPublico, a journalistic cooperative founded entirely by former employees of the extinct Publico newspaper, which is financed by donations from its readers. Also, through crowdfunding platforms like Verkami some journalists get funds to do freelance work. Jordi Pérez-Colomé, for example, collects donations to make his reports through his blog Obama World. These and other success stories show that, through the Internet, direct funding by the audience allows citizen journalism, which no longer requires the intermediary role of the newspaper company.

In mobile environments (tablets and smartphones) there is an extension of the business model and revenue sources used in the cybermedia. With respect to advertising, both in access to mobile web content and through apps such as App Store or Google Play, online media use the typical Internet graphic formats with rich media variants. The major innovation comes from the so-called targeted advertising (nonintrusive advertising) with contextual or behavioural targeting (Castellet, 2012, p. 227). Targeted advertising is usually associated with location services (such as The Scoop). New products also result from the data analysis (data mining), 
suitable for branded content (advertising combined with entertainment) and contextual advertising.

For its part, multiplatform distribution provides incentives for direct payment, with version options depending on the consumer device. This achieves what Bakos and Brynjolfsson (1999) called the rebundling technique, which allows a marketing policy with price differentiation depending on the distribution platform and the content offered. For example, The New York Times offers three subscription modes:

- to the digital edition (nytimes.com) and tablet apps;

- to the digital edition (nytimes.com) and smartphone apps;

- to all digital platforms.

According to studies by the Alliance for Audited Media ( $A A M$, formerly Audit Bureau of Circulations) in the U.S., the success of The New York Times strategy, with over 676,000 subscribers, is due to the aforementioned multiplatform strategy with unlimited access to any device.

On a mixed model the structure of financing varies, ranging from preminence of free to preeminence of fee for content, depending on the content types

In Spain, if one looks at the most-downloaded apps for Apple's smartphone (iPhone) and tablet (iPad) users in the communications media category, according to the annual ranking in App Store Rewind 2011, Orbyt appears first in payment apps, followed by Kioskoymás. With respect to the free apps, it is interesting to note how the ranking varies depending on the downloading platform: elpais.com and elmundo.es (for iPad) and lasextaendirecto, los40.com, marca.com and rtve.es (for iPhone). The comparison of the most downloaded applications by platform shows differential content consumption between the two devices.

\section{Conclusions}

The study of the economic logic of cybermedia highlights the need to establish as its starting point a theoretical framework for making progress in the description of their defining elements. The academic literature reviewed shows that, together with the study of the digitization impact and the emergence of the Internet on traditional media, the cybermedia industry (also called online media) begins to be studied as a differential communications market and characterized by a migration of audiences and revenues, especially advertising.

According to the model for the study of media economics, and in order to describe the cybermedia business model, we have addressed the competitive environment of communications and cultural industries on the Internet. To meet this objective, we began with an analysis of the new content distribution models based on aggregation and the transmedia distribution. We observed that, while the digital environment amplifies the content distribution possibilities for traditional media companies, it also brings the challenge of

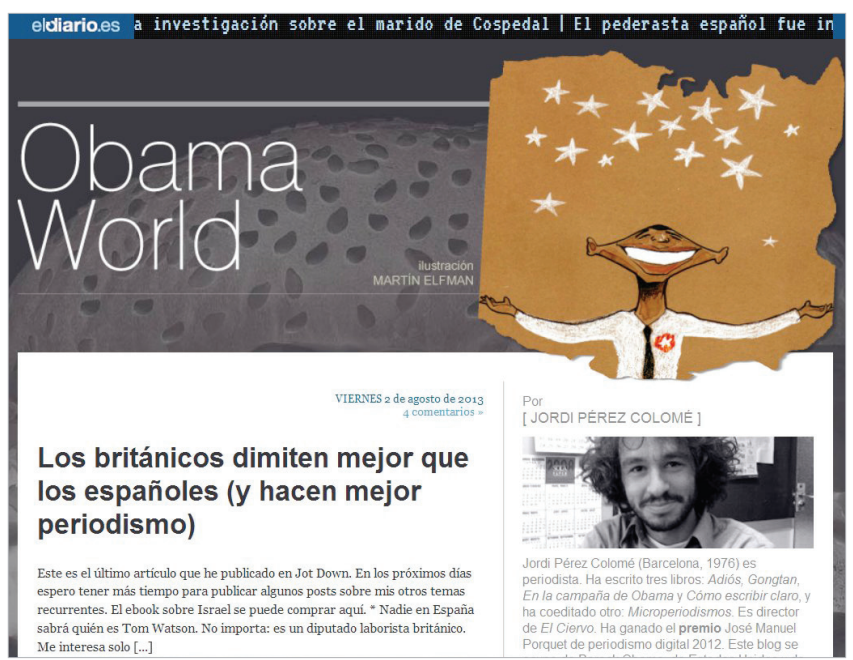

http://www.obamaworld.es

monetizing that content on the internet and in mobile environments. In this sense, competition from native companies (pure players) shows how models of third-party content aggregation can generate significant advertising revenues, and even by fee-for-content.

Having described the competitive environment, the business model of cybermedia was studied by describing the structure of financing. The different sources of income were classified into two groups:

a) advertising, including display advertising ${ }^{5}$, classified, text and graphical advertising, affiliation networks, etc.; and

b) paid content, which includes subscription and micropayment on the Internet and in mobile environments, and the sale of content to third parties through syndication and content aggregation. This group also includes donations and grants (journalism crowdfunding), and ultimately user payments made to fund journalism.

\section{If Internet is compared with the rest of media, only television and radio get more funding from advertising}

The various studies analyzing cybermedia financing sources allow us to conclude:

1 ) in the evolution of the various sources of financing, advertising is a constant and, to a lesser extent, so is payment for content;

2) despite the many efforts to increase payment for content, advertising revenues continue to dominate the income statement.

Finally, we note the importance of continuing studies evaluating the relationship between the type of content and the funding model because in online and mobile environments, as in the press or on TV, it is not so much the medium that defines the revenue model, but the type of product. This explains why the Internet consolidates the mixed model, which modulates a revenue structure that ranges from the preeminence of free to the prominence of fee-for-content, depending on content type. 


\section{Notes}

1. This fee would apply to the advertising revenue generated by search engines that aggregate news from other digital media. The reasons the editors advance are that, according to various studies, 8 out of 10 news items have their origin in the press (Cortés; Martínez-de-Aguirre, 2013), while Google and other search engines account for $60 \%$ of interactive advertising. Following the open battle between Google and publishers, the company modified the news aggregation system, so that newspaper publishers decide if they want their news to be indexed in Google News or excluded, as in Brazil after the decision by the Asociación Nacional de Periódicos (National Newspaper Association). In other countries the conflict with Google is taking different paths, closer to the agreements between the parties achieved in France and Belgium than to government imposition of a fee, as has been implemented in Germany and is being considered in the draft of the Intellectual Property Law (known as Lassalle Law) in Spain.

2. An affiliate network acts as an intermediary between publishers (affiliates) and merchant affiliate programs. It allows website publishers to more easily find and participate in affiliate programs which are suitable for their website (and thus generate income from those programs), and allows websites offering affiliate programs (typically online merchants) to reach a larger audience by promoting their affiliate programs to all of the publishers participating in the affiliate network.

http://en.wikipedia.org/wiki/Affiliate_network

Among the companies engaged in affiliate marketing, managing advertising campaigns, there is Antevenio, which was the first Spanish company to be listed on the Alternext Paris market; another is Affilinet, which has a significant presence in Europe, as well as Netaffiliation that has a presence in over 15 countries in Europe and America, and more than 100,000 affiliate websites, and the Swedish company TradeDoubler, which works with more than 140,000 media.

3. A pay-wall (or paywall) is a system that prevents Internet users from accessing webpage content (most notably news content and scholarly publications) without a paid subscription. There are both "hard" and "soft" paywalls in use. "Hard" paywalls allow minimal to no access to content without subscription, while "soft" paywalls allow more flexibility in what users can view without subscribing, such as selective free content and/or a limited number of articles per month, or the sampling of several pages of a book or paragraphs of an article. Newspapers have been implementing paywalls on their websites to increase their revenue, which has been diminishing due to a decline in print subscriptions and advertising revenue.

http://en.wikipedia.org/wiki/Paywall

4. The Interactive Advertising Bureau (IAB) provides the following types of interactive advertising: display advertising (banners and other textual or multimedia formats), search advertising (f.i. sponsored links by keywords), and classified ads.

5. In print, display advertising generally refers to the full-page ads that run in the main editorial sections of a magazine, as opposed to the smaller, often text-heavy classified ads at the back of the book. Advertisers would pay a premium rate for display ads, but not merely because they could use colors and pictures in the ads. They paid a premium because display ads did more than drive calls to the phone banks; the adjacency to the editorial content and the association with the publication's brand helped advertisers create demand among readers who didn't yet know they wanted or needed something.

http://chasnote.com/2009/01/20/display-advertising-vgraphical-ads

6. This article is a result of the R\&D project "Innovación y desarrollo de los cibermedios en España. Aplicaciones y tecnologías para la producción, distribución y consumo de información" (Innovation and development of online media in Spain. Applications and technologies for information production, distribution and consumption), assigned to the coordinated project "Innovación y desarrollo de los cibermedios en España" (Innovation and development of online media in Spain) (ref. CSO2012-38467-C03-01). Ministerio de Economía y Competitividad, Spain.

\section{Bibliography}

Albarran, Alan (1996). Media economics: understanding markets, industries and concepts. lowa: lowa State University. ISBN: 0813821282

Albarran, Alan (2010). The media economy. London: Routledge. ISBN: 9780415990462

Albarran, Alan; Chan-Olmsted, Sylvia (eds.) (1998). Global media economics: commercialization, concentration and integration of world media markets. Ames: lowa State University Press. ISBN: 081382690X

Amitt, Raphael; Zott, Christoph (2001). "Value creation in e-business". Strategic management journal, v. 22, n. 6-7, pp. 493-520.

http://dx.doi.org/10.1002/smj.187

Bakos, Yannis; Brynjolfsson, Erik (1999). "Bundling information goods: pricing, profits, and efficiency". Management science, v. 45, n. 3, pp. 1613-1630.

http://people.stern.nyu.edu/bakos/big.pdf

http://dx.doi.org/10.1287/mnsc.45.12.1613

Bolin, Göran (2007). "Media technologies, transmedia storytelling and commodification". En: Storsul, Tanja; Stuedahl, Dagny (eds). Ambivalence towards convergence: digitalization and media change. Nordicom: Göteborgs Universitet, Göteborg, pp. 237-248. ISBN: 9789189471504

Brody, Jeffrey H. (2000). "The structure of the internet industry". En: Greco, Albert (ed.). The media and entertainment industries: readings in mass communications. Boston: Allyn and Bacon, pp. 248-267. ISBN: 0205300103

Bustamante, Enrique (1988). Las industrias culturales en España. Madrid: Akal. ISBN: 9788476003398

Bustamante, Enrique (coord.) (2002). Comunicación y cultura en la era digital: Industria, mercados y diversidad en España. Barcelona: Gedisa. ISBN: 847432985 X 
Carveth, Rod (2004). "The economics of online media". En: Alexander, Alison; Owers, James; Carveth, Rodney; Hollifield, C. Ann; Greco, Albert (Eds.). Media economics. Theory and practice. New Jersey: Lawrence Erlbaum Associates, pp. 265-282. ISBN: 0805845801

Casero-Ripollés, Andreu (2010). "Prensa en internet: nuevos modelos de negocio en el escenario de la convergencia". El profesional de la información, v. 19, n. 6, pp. 595-601. http://eprints.rclis.org/15015/1/595-601.pdf http://dx.doi.org/10.3145/epi.2010.nov.05

Castellet, Andreu (2012). El ecosistema del contenido móvil. Tesis doctoral, Universidad de Murcia.

http://www.tdx.cat/handle/10803/96331

Cea-Esteruelas, María-Nereida (2009). “Modelo de negocio de la empresa periodística en internet: el caso de Prisa". Revista latina de comunicación social, n. 64, pp. 938-950. http://www.revistalatinacs.org/09/art/872_UMA/73_99_ Nereida_Cea_Esteruelas.html

Cea-Esteruelas, María-Nereida (2010). “Introducción al concepto de empresa periodística en Internet". Estudios sobre el mensaje periodístico, n. 16, pp. 31-43.

http://revistas.ucm.es/index.php/ESMP/article/view/ ESMP1010110031A

Cebrián, Mariano (2009). “Comunicación interactiva en los cibermedios". Comunicar, n. 33 v. 17, pp. 15-24.

http://www.revistacomunicar.com/index.php?contenido $=d$ etalles \&numero $=33$ \&articulo $=33-2009-03$

http://dx.doi.org/10.3916/c33-2009-02-001

Champion, Katherine; Doyle, Gillian; Schlesinger, Philip (2013). Quality, diversity and innovation: their role in the economic functioning of the media industries. Researching diversity of content in a multi-platform context.

http://www.gallb/adder-research.org/media/ media_246977_en.pdf

Chyi, Iris; Sylvie, George (1998). "Competing with whom? Where? And how? A structural analysis of the electronic newspaper market". Journal of media economics, v. 2, n. 11. http://dx.doi.org/10.1207/s15327736me1102_1

Chyi, Iris; Sylvie, George (2010). "Are long-distance users an inconvenient truth? Profiling U.S. newspapers' online readership in the dual-geographic market". International journal on media management, v. 12, n. 2, pp. 93-112.

http://journalism.utexas.edu/sites/journalism.utexas.edu/ files/attachments/graduate/ChyiSylvie2010.pdf http://dx.doi.org/10.1080/14241277.2010.509850

Colapinto, Cinzia (2010). "Moving to a multichannel and multiplatform company in the emerging and digital media ecosystem: the case of Mediaset Group". International journal on media management, v. 12, n. 2, pp. 59-75.

http://www.tandfonline.com/doi/pdf/10.1080/14241277.2 010.510459

http://dx.doi.org/10.1080/14241277.2010.510459

Cortés, Blanca; Martínez-de-Aguirre, Javier (2013). "Google vs Aede: un conflicto por resolver". Cinco días, 8 de febrero. http://www.cincodias.com/articulo/opinion/google-vsaede-conflicto-resolver/20130208cdscdsopi_1

Díaz-Noci, Javier (2008). “Definición teórica de las características del ciberperiodismo: elementos de comunicación digital". Doxa comunicación: revista interdisciplinar de estudios de comunicación y ciencias sociales, v. 6, pp. 53-91. http://www.humanidades.uspceu.es/pdf/Articulo2Definicionteoricadelascaractdelciberperiodismo.pdf

Diezhandino, María-Pilar (2012). “El periodismo sólo sobrevivirá si ofrece un modelo de información de pago, según un informe de Fundación Telefónica". Fundación Telefónica, 3 de octubre. http://www.fundacion.telefonica.com/es/que_hacemos/ noticias/detalle/03_09_2012_esp_2292

Doyle, Gillian (2003). Understanding media economics. London: SAGE. ISBN: 9780761968757

Faustino, Paulo (2007). "Becoming a broadcasting leader in 10 years: a case study of Portugal's TVI-Media Capital Group". International journal on media management, v. 9, n. 4.

http://dx.doi.org/10.1080/14241270701632712

Fetscherin, Marc; Knolmayer, Gerhard (2004). "Business models for content delivery: an empirical analysis of the newspaper and magazine industry". International journal on media management, v. 6, n. 1-2.

http://www.mediajournal.org/ojs/index.php/jmm/article/ viewFile/285/180

http://dx.doi.org/10.1080/14241277.2004.9669377

Goldhaber, Michael (1997). "The attention economy and the Net". First Monday, v. 2, n. 4.

http://www.firstmonday.org/issues/issue2_4/goldhaber

Guallar, Javier; Rovira, Cristòfol; Ruiz, Sara (2010). "Multimedialidad en la prensa digital. Elementos multimedia y sistemas de recuperación en los principales diarios digitales españoles". El profesional de la información, v. 19, n. 6, pp. 620-629.

http://eprints.rclis.org/15088/1/620-631-Guallar-RoviraRuiz.pdf

http://dx.doi.org/10.3145/epi.2010.nov.08

Herrero, Mónica (2002) Pago directo, programación y audiencias. Canal Plus España. Tesis doctoral. Universidad de Navarra.

Jones, Daniel (2005). “Aproximación teórica a la estructura de la comunicación social". Sphera publica, v. 5, p. 19-39. http://sphera.ucam.edu/index.php/sphera-01/article/ download/20/30

Magretta, Joan (2002). "Why business models matter". Harvard business review, v. 80, p. 86-92.

http://rushkolnik.ru/tw_files2/urls_2/135/d-134406/7zdocs/10.pdf

Miguel-de-Bustos, Juan-Carlos (2000). "Industrias culturales: gratuidad y precios en internet". Zer: Revista de estudios de comunicación, v. 9.

http://www.ehu.es/zer/es/hemeroteca/articulo/industriasculturales-gratuidad-y-precios-en-internet/123 
Millán, Juan-Luis (1993). La economía de la información: análisis teóricos. Madrid: Trotta. ISBN: $848769974 X$

Nieto, Alfonso; Iglesias, Francisco (2000). Empresa informativa. Barcelona: Ariel. ISBN: 9788434412828

Oelbermann, Martin; Secheibenbogen, Sylvia; Reibnitz, Alexander; Shierstädt, Maximilian (2004). Online publishing in Europe. Markets, strategies, revenue streams. Berlin: Online Publishers Association Europe.

Owers, James; Carveth, Rodney; Alexander, Alison (2003). "An introduction to media economics theory and practice". En: Alexander, Alison; Owers, James; Carveth, Rodney; Hollifield, C. Ann; Greco, Albert (Eds.). Media economics. Theory and practice. New Jersey: Lawrence Erlbaum Associates, pp. 3-49. http://www.rasaneh.org/Images/News/AtachFile/12-2-1391/ FILE634714659375844297.pdf

Picard, Robert (1989). Media economics: concepts and issues. London: Sage. ISBN: 0803935021

Rayport, Jeffrey; Sviokla, John (1995). "Exploiting the virtual value chain". Harvard business review, pp. 75-85. http://hbr.org/1995/11/exploiting-the-virtual-value-chain/ar/1

Salaverría, Ramón (coord.) (2005) Cibermedios: el impacto de internet en los medios de comunicación en España. SeviIla: Comunicación Social. ISNB: 9788496082335

Ricart, Enric (2009). "Modelo de negocio: el eslabón perdido en la dirección estratégica". Universia business review, n. 23, pp. 12-25.

http://ubr.universia.net/pdfs_web/UBR_2300912.pdf

Rojo, Pedro-Antonio (2008). Modelos de negocio y consumo de prensa en el contexto digital. Murcia: Universidad de Murcia. ISBN: 9788483717448

Rosenstiel, Tom (2013). The state of the news media 2013.
An anual report on American journalism. http://stateofthemedia.org

Scolari, Carlos (2013). "Narrativas transmedia, McLuhan y el discurso científico". Cccblab. Investigación e innovación en cultura, 15 de enero.

http://blogs.cccb.org/lab/es/narratives-transmediamcluhan-i-el-discurs-cientific

Shafer, Scott; Smith, H. Jeff; Linder, Jane (2005). “The power of business models". Business horizons, v. 48, pp. 199-207. http://meconsultingassignments.com/Docs/E-Business/ Shafer_2005_Business-Horizons.pdf

http://dx.doi.org/10.1016/j.bushor.2004.10.014

Shapiro, Carl; Varian, Hal (2000). El dominio de la información. Una guía estratégica para la economía de la Red. Barcelona: Antoni Bosch. ISBN 9788485855971

Tallón-García, José (1992). Lecciones de empresa informativa. Madrid: Ediciones Ciencias Sociales. ISBN: 978 8487510281

Tapscott, Don (1997) La economía digital. Santafé de Bogotá: McGraw-Hill Interamericana. ISBN: 9788483108550

Taúler, Miguel; Población, José-Ignacio (eds.) (2000). Estudios de empresa informativa. Homenaje al profesor José Tallón. Madrid: Facultad de Ciencias de la Información, Universidad Complutense de Madrid. ISBN: 9788460095880

Timmers, Paul (1998). "Business models for electronic markets". Electronic markets, v. 8, n. 2, pp. 3-8.

http://www.cs.uu.nl/docs/vakken/ec/Timmers_BMem.pdf

Wirtz, Bernd W. (2011). Media and internet management. Wiesbaden: Gabler Verlag. ISBN: 9783834930101 http://berndwirtz.com/downloads/mim_extract.pdf http://berndwirtz.com/downloads/mim_Im_extract.pdf

\section{Próximos temas centrales}

Septiembre 2013

Noviembre 2013

Enero 2014

Marzo 2014

Mayo 2014

Julio 2014

Septiembre 2014
Gestión de contenidos

Formación y aprendizaje

Documentación audiovisual

Políticas de información

Humanidades digitales

Big data y analítica web

Marketing

Los interesados por favor consulten detenidamente las Normas para autores:

http://www.elprofesionaldelainformacion.com/autores.html

y luego envíen sus artículos a través del gestor de manuscritos OJS de la plataforma del Recyt: http://recyt.fecyt.es/index.php/EPI/index 